\title{
Gender Differences of Advertising Spokespersons in Marketing
}

\author{
Yanni Li , Lingling Ma,Yiqun Liu, Longqun Li, Shuang Sun \\ School of Foreign Languages, Changchun Institute of Technology, Jilin 130012, China; \\ aliyanni2007@163.com
}

Keywords: advertising; spokesperson; gender differences; mechanical impression

\begin{abstract}
With the mature of the market economy, marketing becomes more important day by day. Advertising is one of the most popular way in marketing strategies. As the carrier of the product information, advertising spokesperson holds the balance of marketing, and the function of the gender differences of advertising spokesperson greatly impact on the marketing. Gender differences exist in the field of advertising widely, and we called this phenomenon as the gender mechanical impression of advertising spokesperson. The gender differences impact on the marketing of target consumers and brand. Everything is changing in the world, we must understand the impact of the advertising spokespersons' gender differences on marketing are changing with the objective world, or we could not get the marketing aim.
\end{abstract}

\section{Introduction}

The news are heard oftern like: England famous soccer star, David Beckham is employed as the advertising spokesperson of Gillette shaver; Ni Hongjie who used to be a teacher but suddenly well known by the advertisement of Taitai(lady)liquid tonic, she is asked to be the spokesperson for the underclothes---Tingmei. When we turn on TV, radio; read newspapers, magazines; or walk on the streets, we could see various kinds of advertising spokespersons, they tell us the information about the commodities or give audiences the demonstration.

There are some kinds of commodities, which always select female as their advertising spokesperson. For example, the Household appliances, cosmetics, baby products. They always choose female as their advertising spokespersons. The most famous example of the female advertising spokesperson is the advertisements of weight reducing products. We could clearly remember the advertisement of weight-reducing medicine- "great impression weight-reducing tea", they select famous female movie stars: Guan Zhilin, Gong Li, Wang Ji as its advertising spokespersons. In the advertisements they tell us "beautiful-loving is nature of female, Great-impression weight-reducing tea, preserving beauty for female". Suddenly, the weight-reducing product of this brand becomes popular, millions of people remember this brand, and soon weight-reducing becomes such a fashionable activity in the world. More than $60 \%$ people who are fond of weight reducing choose "Great-impression tea" as their first choice. And then, other brands of weight-reducing medicines appear, they also use advertisement as their first choice to be their marketing tool. But the common point is that the advertising spokespersons of their products are all female. The female spokesman of weight-reducing medicines is. If they choose men as their advertising spokesmen, we will feel so strange, and these commodities could not attract women to buy it [1].

But not all kinds of advertising spokespersons are female, such as sports equipments, automobiles, etc, they usually choose male as their advertising spokespersons. There is a famous advertisement which is for First Automobiles Corporation's new designed car---Candy. The spokesman of this Ad is Jacky Chung, the famous Hong Kong movie star. In the advertisement Jacky Chung uses his Kongfu to avoid a traffic accident to tell us what excellent performance of the car is. 


\section{Functions of advertising spokesperson}

Companies always spend millions of money on the advertising spokespersons employing, and what is the magic of spokespersons to get such a large amount of money from the companies? The answer is the functions of them.

1) To be the media of the propaganda. It means they should propaganda the commodity information through the advantages of themselves and cooperates with the propaganda activities that arranged by the company.

2) To transfer the information of the brand. Different companies have different entrepreneur culture, the spokespersons should spread out the features of the company that employ them to let the consumers could clearly divide them. Because no one wants to buy the goods that are the same as others, the particularity of the goods could attract the consumers to buy it.

3) Enlarge the popularity of the commodity. People are always willing to buy the goods which is well known by the population, the first step of advertisement is to let the population to remember the goods of the brand of the goods, then when they choose the commodities in the super market they will naturally choose the commodities which they have remembered.

\section{The impact of advertising spokespersons' gender differences on marketing}

The gender differences in advertising are an important measurement for the marketers to segment their target market[2]. According to different gender characteristics to design different types of advertisement, marketing is composed by the consumers who have the purchasing demand, the purchasing ability, and purchasing desires. It is influenced by age, sex, income, education, geography and psychology, so different consumers usually have different desires and demands; therefore. Different consumers also have different purchase action and purchase habit. Just because of this, marketers should segment different market accord to it, and every market as equal as a consumers group that has resemble desire. The market segmenting could classify target consumers quickly, and they are the warrant of the advertising. To use different advertising by different target consumers so as to make the advertising get the best reward.

In the eyes of every advertiser, gender is the important guideline of the market segmenting, because consumers are either men or women, or both of them, what the advertising want to show, or what kind of method should be adopted is really important. After they ensure the gender of the target consumers and the content, the performance of the advertising is suitable to them. Then, the effeteness of the advertising will be elevated greatly.

With the introduction of the spokesperson, marketing, and marketing strategy, we could get the information that these aspects are linked together. The relation between them are very complex, the marketing strategy is a part of marketing, and advertising spokesperson using is a kind of tool in marketing strategy. Marketing is composed of marketing strategy, marketing purpose, and marketing positioning. Usually we consider that the marketing positioning decide which kind of marketing strategy using; and marketing strategy decide the spokesperson using, even it could decide the gender of advertising spokesperson. But in fact, the gender different could also impact on target consumers.

1) Different purchasing psychology of men and women

To compare with female, male is more reasonable and self-confident, their purchase decisions come more resolute and faster, and the feeling of enticement and freshness can evoke their purchase desire sooner often. In this way, to compared with women, man will be more interested in selling POP (the advertisement of sales outlet) of the scene, and easier to accept. For example: Advertisement of show window, advertisement of the counter, the advertisement of the supermarket, advertisement of packing, demonstrating live, the model demonstrates, is it try out in sales outlet advertising form these more valid to male excited consumption of consumer to have a try.

According to the purchasing psychology of men, the advertisement should emphasis on the female's characteristics to arouse the interest of man. And the company should ask the advertising spokesperson to take part in the live selling, do more live advertisement and design the package of the product different with other, to position the product that is cool, manly, and vigorous to transfer the information that the product is designed by the men those beloved by women. 
Because of the gender differences, the advertising spokesperson's gender mechanical impression comes into being. And more or less, the mechanical impression of men and women will impact on the population and people's ways of thinking. We must be very clear about the gender differences of the advertising spokesman, it is very important for the advertisement position, advertising spokesperson adoption, and the marketing strategy programming.

2) Process of purchasers' psychology activities

The companies spend such a large amount of money on employing the advertising spokesperson to propaganda product not only in order to use the advertisement as the tool to attract the customer or spread out the best potency, but also to get the profit by arousing consumers' desire, urges them to purchase, and then lastingly use the product. The information that is successfully transmitted in the advertisement firstly affects consumer's vision and the sense of hearing, subsequently stimulates their psychology to induce, promote a series of psychological activities, and finally causes consumer's purchase behavior. Only when the companies clearly master the psychology of the consumers, they could design the marketing plan, product positioning, and target market positioning more correctly. Then, they should according to these aspects decide the ways of propaganda, whether they need advertisement, or advertising spokesperson. If the answer is yes, they should think about the $q$ selection of the advertising spokesperson. Usually, the companies persuade the customers back and forth, just in order to arouse their desire to buy the goods. The persuader must understand the consumers' psychology before and after they purchase the commodity, such as: their self-respect, realism, beauty-loving, economical attitude, happiness -seeking, personal glory, and so on[3].

\subsubsection{The impact of spokespersons' gender differences on product positioning}

Positioning is another term for fitting the product into the lifestyle of the buyer. It refers to segmenting a market by either or both of two ways:(1) creating a product to meet the needs of a specialized group, and/or (2) identifying and advertising a feature of an existing product that meets the needs of a specialized group. The purpose of positioning is giving a product a meaning that distinguishes it from other products and induces people who want to buy it. Positioning is what you do to the mind of the customer. Specifically, you position the product in the mind of the prospect.

The national cell phone---Bird, employed Coco Lee as the advertising spokesperson for its products. The corporation positions the cell phone as a communication tool for both men and women. But the advertising words are: "Bird cell phone is the fighter plane in the field of cell phone". Then, a lot of women consider the cell phone is designed for male, and most of men consider the cell phone is designed for female, because the advertising spokesperson is female.

By this example we know that products positioning is really subjective, the advertising spokesperson is a carrier to show the characteristics of the products; and gives the audience a vivid impression of the product positioning. So gender differences of the spokesperson always firstly be noticed by the audience, and then they will reposition the product by themselves according to the sex or the personality of the spokesperson.

\subsubsection{The impact of spokespersons' gender differences on brand marketing}

A brand name is often an organization's most valuable asset because it provides customers with a way of recognizing and specifying a particular product so that they can choose it again or recommend it to others. This notion of the value of a brand is also called brand equity. Strong brands often command a premium price in the marketplace, as Nike shoes, the North Face ski wear, Bobbie Brown cosmetics, and Evian water do.

Customers who buy the same brand again and again are evidence of the strength of brand loyalty, or commitment to a particular brand. Brand loyalty can be measured in degrees. The first level is brand awareness, which means that people are likely to buy a product because they are familiar with it. The next level is brand preference, which means people will purchase the product if it is available, although they may still be willing to experiment with alternatives if they cannot find the preferred brand. The third and ultimate level of brand loyalty is brand insistence, the stage at which buyers will accept no substitute.

The famous brand is not established in one day, it has a process from new establish brand to famous brand. But not every company could establish his brand; it needs rational management; 
excellent quality and correct marketing strategies. Companies can take various approaches to building brands. But they must notice the impact of advertising spokespersons' gender differences on brand marketing.

1) Impact on new brand marketing

The new brands always employ famous stars as their advertising spokespersons, because the companies need the spokesperson's popularity and attractiveness to appeal the attention of audience[4]. But the gender of the advertising spokesperson must conform to the products positioning.The gender mechanical impression influences on us deeply. The spokesperson of the products such as shaver, suit, wine and cigarette had better select men. Because the male advertising spokesperson could give the consumers truly feeling of the product using, and be the mirrors for the consumers. So people are easier to accept it. If the company can do more supermarket advertisement, show window advertisement according to the purchase psychology of the men, it will be more effective.

2) The impact on famous brand

The famous brands have millions of loyal supporters and their own characteristics; so they have the ability to create the new rules in their field to enlarge their impact on the market. The advertising spokesperson is the carrier for them to get this aim. Such as Johnson's baby no tears bath foam, they establish the image of a lovely father who is taking bath for his little son. When the young father takes bath for baby, he finds the shampoo will make his baby's eyes uncomfortable; he chooses Johnson's no tears baby foam for his son. And the baby plays with his young father so happily in the bath time. This advertisement expresses the young, lovely father's love to his son. It is the image of the good husband in the heart of modern women and a lovely father of the baby. And the advertisement broke the rule that the spokesperson of baby products must be women.

\section{Summary}

Generally, we must emphasis on the particularity of men's product and lady's product. We should carefully research the psychological differences of men and women, and then design the marketing strategy. When we design the advertisements that represented by male advertising spokesperson, we should put much more emphasis on the theme and subject of advertisement; we could concentrate on their successful career, glamour personality, the heroism, firm-mind, free and easygoing, magnanimous, straightforward personality. To the advertisements that use women as their spokespersons, we should particularly stress on the features of emotion, such as sympathy, love, harmonious and warm, beautiful, kindhearted, hardworking for their family, graceful and elegance. The impact of the advertising spokespersons' gender differences on marketing is also changing, in order to get a better impression; advertisers must modify their opinion according to the objective situation.

\section{Acknowledgements}

The authors would like to give their thanks to The Education Department of Jilin Province (NO. 2015-201) and National Program of Business Startups for University Students (2015-31; 2015-32) for their financial and technical support.

\section{References}

[1]. Edens, K. M. \& McCormkck, C.B. How Do Adolescents Process Advertisements, The Influence of Ad Characteristics, Processing Objective, and Gender. Contemporary Educational Psychology, 2000, p36-42.

[2]. P.H. Miller \& E. K Scholnick (Eds.). Toward a feminist developmental psychology. New York: Routledge, 2000, p60-62.

[3]. Evelyne Hong. Women as Consumers and Producers in the World Market.Beijing: Sanhuan press, 2002, p70-75.

[4]. Saucier, D. M. \& Elias, L. J, Lateral and Sex Differences in Manual Gesture During Conversation. Laterality, 2001,6,p20-26. 